\title{
Particle hygroscopicity during atmospheric new particle formation events: implications for the chemical species contributing to particle growth
}

\author{
Z. Wu, W. Birmili, L. Poulain, L. Poulain, M. Merkel, B. Fahlbusch, D. van Pinxteren, H. Herrmann, and \\ A. Wiedensohler \\ Leibniz Institute for Tropospheric Research, Permoserstraße 15, 04318 Leipzig, Germany \\ Correspondence to: Z.Wu (wuzhijun@tropos.de)
}

Received: 11 April 2012 - Published in Atmos. Chem. Phys. Discuss.: 3 May 2012

Revised: 10 June 2013 - Accepted: 12 June 2013 - Published: 12 July 2013

\begin{abstract}
This study examines the hygroscopicity of newly formed particles (diameters range $25-45 \mathrm{~nm}$ ) during two atmospheric new particle formation (NPF) events in the German mid-level mountains during the Hill Cap Cloud Thuringia 2010 (HCCT-2010) field experiment. At the end of the NPF event involving clear particle growth, we measured an unusually high soluble particle fraction of $58.5 \%$ at $45 \mathrm{~nm}$ particle size. The particle growth rate contributed through sulfuric acid condensation only accounts for around $6.5 \%$ of the observed growth rate. Estimations showed that sulfuric acid condensation explained, however, only around $10 \%$ of that soluble particle fraction. Therefore, the formation of additional water-soluble matter appears imperative to explain the missing soluble fraction. Although direct evidence is missing, we consider water-soluble organics as candidates for this mechanism. For the case with clear growth process, the particle growth rate was determined by two alternative methods based on tracking the mode diameter of the nucleation mode. The mean particle growth rate obtained from the inter-site data comparison using Lagrangian consideration is $3.8( \pm 2.6) \mathrm{nm} \mathrm{h}^{-1}$. During the same period, the growth rate calculated based on one site data is $5.0 \mathrm{~nm} \mathrm{~h}^{-1}$ using log-normal distribution function method. In light of the fact that considerable uncertainties could be involved in both methods, we consider both estimated growth rates consistent.
\end{abstract}

\section{Introduction}

New particle formation (NPF) has been observed in almost any part of the earth's atmosphere (Kulmala et al., 2004). NPF is an important source of atmospheric particles and likely contributes to the balance of optically active particles (Kulmala et al., 2011), and cloud condensation nuclei (Spracklen et al., 2008; Wiedensohler et al., 2009; Wang and Penner, 2009; Laaksonen et al., 2005; Yue et al., 2011). NPF has thus the potential to influence climatologically important processes such as precipitation patterns and earth's energy balance (IPCC, 2007). However, the mechanisms of atmospheric nucleation and particle subsequent growth still remain unclear. Sulfuric acid is the main species thought to be responsible for atmospheric NPF (Brus et al., 2011; Kulmala et al., 2006; Sipilä et al., 2010). Recently, sufficient evidences showed that organics also play important roles (e.g., Zhang et al., 2004; Kiendler-Scharr et al., 2009; Wang et al., 2010; Ristovski et al., 2010).

To quantitatively understand the NPF and subsequent growth process, it is critical to obtain information on the chemical species involved. Recently, novelty instruments, such as thermal desorption chemical ionization mass spectrometry, were developed and used to measure the particle chemical composition of sub-20 nm (Smith et al., 2004, 2005; Barsanti et al., 2009; Smith et al., 2010; Zordan et al., 2008). Due to the tiny particle masses involved, the direct determination of chemical composition of newly formed particles is still a tedious task. Alternatively, measurements of particle volatility and/or hygroscopicity have been referred to provide indirect information on the chemical species 
contributing to particle growth (Väkevä et al., 2002; Sakurai et al., 2005; Wehner et al., 2005; Ehn et al., 2007; Petäjä et al., 2007; Asmi et al., 2010; Ristovski et al., 2010; Modini et al., 2009).

Both sulfuric acid and organic compounds were found to contribute to the subsequent particle growth after nucleation (e.g., Smith et al., 2004; Yue et al., 2010; Pierce et al., 2011; Ehn et al., 2007). Their relative fraction in the particle phase seems to depend on the type of atmospheric environment (e.g., Boy et al., 2005; Yue et al., 2010; Stolzenburg et al., 2005). In the polluted atmosphere of Atlanta, USA, the available amount of sulfuric acid was sufficient to explain all of the observed particle growth (Stolzenburg et al., 2005), however, sulfuric acid represents only $30 \%$ of the newly formed particles in the rural atmosphere of Hohenpeissenberg, Southern Germany (Birmili et al., 2003), and only around $10 \%$ in the boreal forest area of Finland (Boy et al., 2005).

Due to the differences in hygroscopicity of sulfuric acid and/or its ammonium salts and secondary organics (Virkkula et al., 1999; Varutbangkul et al., 2006; Tang and Munkelwitz, 1994), the hygroscopicity measurements can provide insight into the changes in condensing vapor properties and chemical composition of newly formed particles during the course of NPF event (Hämeri et al., 2001; Ehn et al., 2007; Ristovski et al., 2010). In Hyytiälä, Finland, the hygroscopicity of the mode of newly formed particles decreased as the modal diameter increased from 10 to $50 \mathrm{~nm}$ during the NPF events, indicating that the vapors responsible for particle growth changed (Ehn et al., 2007). They also observed that the hygroscopicity of $10 \mathrm{~nm}$ particles significantly varied with different events and stressed that the mechanism producing these particles is different.

In this study, the particle number size distributions and particle hygroscopicity at a mid-level mountain site in Germany were measured during the field experiment Hill Cap Cloud Thuringia 2010 (HCCT-2010). Two NPF events with different features could be characterized in much detail. Based on the hygroscopicity measurements of the nucleation mode and additional numerical calculations, the possibilities of various chemical species contributing to the detected growth of the nucleation mode are evaluated. Finally, the particle growth rate was respectively determined using lognormal distribution function method and Langragian consideration.

\section{Experiments}

\subsection{Measurement sites}

The HCCT-2010 field campaign was performed in September and October 2010 in the Thüringer Wald mid-level Mountain in central Germany. During the campaign, three research stations were employed: Schmücke $\left(10^{\circ} 46^{\prime} 15^{\prime \prime} \mathrm{E}\right.$, $50^{\circ} 39^{\prime} 19^{\prime \prime} \mathrm{N}$, the summit of the mountain, $937 \mathrm{~m}$ above sea level, a.s.1.), Goldlauter $\left(10^{\circ} 45^{\prime} 20^{\prime \prime} \mathrm{E}, 50^{\circ} 38^{\prime} 25^{\prime \prime} \mathrm{N}, 605 \mathrm{~m}\right.$ a.s.1.), and Gehlberg $\left(10^{\circ} 47^{\prime} 32^{\prime \prime} \mathrm{E}, 50^{\circ} 40^{\prime} 21^{\prime \prime} \mathrm{N}, 732 \mathrm{~m}\right.$ a.s.1.). The research stations are surrounded by forest. The dominant trees are Norway spruces $(8-23 \mathrm{~m})$. A more detailed description about the sampling sites can be found in Herrmann et al. (2005).

\subsection{Particle hygroscopicity measurements}

The particle hygroscopicity was investigated using a hygroscopicity tandem differential mobility particle analyzer (HTDMA). The HTDMA used in this study has been illustrated in previous publications in detailed (Wu et al., 2011; Massling et al., 2003), and complies to the instrumental standards prescribed in Massling et al. (2011). The H-TDMA consists of three main parts: (1) Differential Mobility Analyzer (DMA1) that selects quasi-monodisperse particles, and a Condensation Particle Counter (CPC1) that measures the particle number concentration leaving the DMA1 at the selected particle size; (2) an aerosol humidifier conditioning the particles selected by DMA1 to a defined relative humidity (RH); and (3) the second DMA (DMA2) coupled with another condensation particle counter (CPC2) to measure the number size distributions of the humidified aerosol. The experiments were conducted in a temperature-controlled container $\left(20^{\circ} \mathrm{C}\right)$. The $\mathrm{RH}$ of the sampling air was kept to below $30 \%$ using an automatic regenerating adsorption aerosol dryer (Tuch et al., 2009).

The hygroscopic growth factor (HGF) is defined as the ratio of the particle mobility diameter, $D(\mathrm{RH})$, at a given $\mathrm{RH}$ to the dry diameter, $D_{\mathrm{d}}$ :

$\mathrm{HGF}(\mathrm{RH})=\frac{D(\mathrm{RH})}{D_{\mathrm{d}}}$.

The TDMAinv method developed by Gysel et al. (2009) was used to invert the HTDMA data. Dry scans (under $\mathrm{RH}<10 \%)$ are used to calibrate any offset between DMA1 and DMA2 and define the width of the HTDMA's transfer function (Gysel et al., 2009). The uncertainty for HGF of ammonium sulfate particles derived at $\mathrm{RH}=90 \%$ is around $2.5 \%$ (Massling et al., 2003).

\subsection{Other useful parameters}

Other measured parameters used in the data analysis and corresponding instruments are given in Table 1. To estimate the sulfuric acid $\left(\mathrm{H}_{2} \mathrm{SO}_{4}\right)$ concentration, we referred to the global radiation data measured at Schmücke rather than Goldlauter because the mountain shadow blocked the sunlight in the morning at Goldlauter.

Backward air mass trajectories arriving at the sampling site were calculated using the NOAA "HYSPLIT-4" trajectory model (Draxler and Hess, 1998). The $72 \mathrm{~h}$ trajectories terminated on a height of $800 \mathrm{~m}$ above ground at 08:00, 
Table 1. Atmospheric parameters and instrumentation from the field experiment HCCT-2010 that are used in this study. All measurements were taken from the Goldlauter station except global radiation, which was taken from the Schmücke (summit) station.

\begin{tabular}{ll}
\hline Parameters & Instruments \\
\hline Dry particle number size distribution (9-900 nm) (RH below 30\%) & Scanning Mobility Particle Sizer (SMPS) (Wiedensohler et al., 2012) \\
Particle chemical composition & High-Resolution Time-of-Flight Aerosol Mass Spectrometer (AMS) (DeCarlo et al., 2006) \\
$\mathrm{NH}_{3}$ & MARGA semi-continuous ambient air monitoring system (ten Brink et al., 2007) \\
$\mathrm{SO}_{2}$ and $\mathrm{O}_{3}$ & TE 49C-TL O monitor, TE43C-TL SO $\mathrm{O}_{2}$ monitor \\
Wind speed, wind direction, air temperature, and global radiation & Davis Vantage Pro2 weather station \\
\hline
\end{tabular}

10:00, 12:00, 14:00, 16:00 and 18:00 local time (UTC+01) will be used in further analysis.

\section{Methodology}

\subsection{Derivation of the soluble particle fraction}

Based on the Zdanovskii-Stokes-Robinson (ZSR) method (Zdanovskii, 1948; Stokes and Robinson, 1966), the HGF of a mixture can be estimated from the $\mathrm{HGF}_{i}$ of the pure components and their respective volume fractions, $\varepsilon_{i}$ (Malm and Kreidenweis, 1997):

$\mathrm{HGF}_{\text {mixed }}=\left(\sum_{i} \varepsilon_{i} \mathrm{HGF}_{i}^{3}\right)^{1 / 3}$.

Here, we assume that two components including soluble and insoluble fractions contribute to the particle growth (also refer to Ehn et al., 2007; Swietlicki et al., 1999). The soluble fraction is assumed as ammonium sulfate, and the insoluble fraction is organics. Then, $\varepsilon$ of soluble fraction can be calculated by

$\varepsilon_{\left(\mathrm{NH}_{4}\right) 2 \mathrm{SO}_{4} \text {-equivalent }}=\frac{\mathrm{HGF}_{\text {measured }}^{3}-1}{\mathrm{HGF}_{\left(\mathrm{NH}_{4}\right)_{2} \mathrm{SO}_{4}-1}^{3}}$,

where $\mathrm{HGF}_{\text {measured }}$ is the HGF of particle measured by HTDMA, and $\mathrm{HGF}_{\left(\mathrm{NH}_{4}\right) 2 \mathrm{SO}_{4}}$ is the HGF of pure $\left(\mathrm{NH}_{4}\right)_{2} \mathrm{SO}_{4}$ particle with the same size. When calculating $\mathrm{HGF}_{\left(\mathrm{NH}_{4}\right) 2 \mathrm{SO}_{4}}$ in different diameters, the parameterizations for $\left(\mathrm{NH}_{4}\right)_{2} \mathrm{SO}_{4}$ water activity developed by Potukuchi and Wexler (1995) and the density reported by Tang and Munkelwitz (1994) are used. The Kelvin term was considered in the calculation.

The assumption of insoluble organic fraction may lead to overestimate the soluble fraction because atmospherically relevant secondary organics typically have a growth factor larger than 1 (e.g., Varutbangkul et al., 2006). This implies that in the presence of several classes of hygroscopic substances, $\varepsilon$ derived from Eq. (3) is only an "equivalent" soluble fraction (i.e., assuming ammonium sulfate as the only

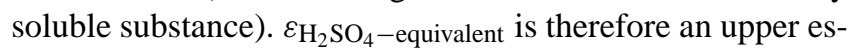
timate for the true soluble volume fraction. The advantage of using soluble fraction term is to allow us analyzing the particle hygroscopicity independently of differences in size.
The uncertainty of the estimated soluble volume fraction is around $5 \%$, which was derived from the measurement uncertainty of HGF $(2.5 \%)$ according to the error propagation function.

\subsection{Estimation of $\mathrm{H}_{2} \mathrm{SO}_{4}$ concentration}

The $\mathrm{H}_{2} \mathrm{SO}_{4}$ concentration is estimated according to the proxy reported by Mikkonen et al. (2011):

$\left[\mathrm{H}_{2} \mathrm{SO}_{4}\right]=8.21 \times 10^{-3} \cdot k \cdot$ Radiation $\cdot\left[\mathrm{SO}_{2}\right]^{0.62}(\mathrm{CS} \cdot \mathrm{RH})^{-0.13}$

where $k$ is the reaction rate constant, which is calculated according to Eq. (3) in Mikkonen et al. (2011) and is scaled by multiplying it with $10^{12}$. CS is the condensation sink, which determines how rapidly molecules will condense onto preexisting aerosols (Kulmala et al., 2005). CS in $\mathrm{s}^{-1}$ is calculated according to Dal Maso et al. (2005) under dry condition. Radiation is global radiation in $\mathrm{W} \mathrm{m}^{-2}, \mathrm{RH}$ is relative humidity in $\% . \mathrm{SO}_{2}$ is the sulfur dioxide concentration in molecules $\mathrm{cm}^{-3}$.

In Mikkonen et al.'s (2011) study, they pointed out the proxy is the worst for predicting $\mathrm{H}_{2} \mathrm{SO}_{4}$ concentration at a mid-level mountain site in Germany (The Meteorological Observatory Hohenpeissenberg, HPB). However, we compared the key variables, which were used in Eq. (4), measured at our measuring site with different sites in Mikkonen et al.'s (2011) paper. It was found that these key variables in our measurement site are more similar to other stations (Melpitz and Hyytiälä) rather than HPB. Therefore, the $\mathrm{H}_{2} \mathrm{SO}_{4}$ concentration estimated by this proxy may not produce an extreme high error. Here, relative error in $\left[\mathrm{H}_{2} \mathrm{SO}_{4}\right]$ estimation using Eq. (4) is considered as $40 \%$ (Mikkonen et al., 2011).

\subsection{Calculation of particle growth rate}

The evolution of the particle number size distribution of nucleation mode over time in the ambient can be well characterised by an evolving log-normal distribution (Stolzenburg et al., 2005; Lee et al., 1984, 1990):

$$
\frac{\mathrm{d} N}{\mathrm{~d} \ln D_{\mathrm{p}}}=\frac{N}{\sqrt{2 \pi Z}} \exp \left(-\frac{\ln ^{2}\left(D_{\mathrm{p}} / D_{\mathrm{g}}\right)}{2 Z}\right),
$$

where $D_{\mathrm{p}}$ is particle diameter, $N$ and $D_{\mathrm{g}}$, are respectively total particle number concentration and geometric number 
mean particle diameter (GMD). Here $Z=\ln ^{2} \sigma_{\mathrm{g}}$, and $\sigma_{\mathrm{g}}$ is geometric number standard deviation of the mode.

The observed growth rate ( $\left.\mathrm{GR}_{\mathrm{obs}}\right)$ can be calculated using the following equation over a certain time period:

$\mathrm{GR}_{\mathrm{obs}}=\frac{\mathrm{d} D_{\mathrm{g}}}{\mathrm{d} t}$.

The growth rate is also calculated using Lagrangian consideration. If there is a good airflow connectivity between two sampling sites (Here upwind site A and downwind site B), the change in particle size can be observed when air mass transported from A to B. Hence, the Lagrangian growth rate $\left(\mathrm{GR}_{\text {Lag }}\right)$ can be estimated:

$\mathrm{GR}_{\mathrm{Lag}}=\frac{D_{\mathrm{g}, \mathrm{B}}-D_{\mathrm{g}, \mathrm{A}}}{\Delta T}$,

where $D_{\mathrm{g}, \mathrm{A}}$ is the GMD of particle number size distribution measured in site A at time $T$, and $D_{\mathrm{g}, \mathrm{B}}$ is the GMD in site B at time $T+\Delta T . \Delta T$ is the time interval during which air parcel travelled from $\mathrm{A}$ to $\mathrm{B}$.

\subsection{Particle growth contributed by $\mathrm{H}_{2} \mathrm{SO}_{4}$ condensation}

Theoretically, the vapor concentration required for growth rate of $1 \mathrm{~nm} \mathrm{~h}^{-1}$ in certain particle size ranges can be calculated according to (Nieminen et al., 2010):

$$
\begin{aligned}
& C_{\mathrm{GR}=1 \mathrm{nmh}^{-1}}=\frac{2 \rho_{\mathrm{v}} d_{\mathrm{v}}}{\gamma m_{\mathrm{v}} \Delta t} \cdot \sqrt{\frac{\pi m_{\mathrm{v}}}{8 k T}} \\
& \quad \cdot\left[\frac{2 x_{1}+1}{x_{1}\left(x_{1}+1\right)}-\frac{2 x_{0}+1}{x_{0}\left(x_{0}+1\right)}+2 \ln \left(\frac{x_{1}\left(x_{0}+1\right)}{x_{0}\left(x_{1}+1\right)}\right)\right],
\end{aligned}
$$

where $x_{0}$ and $x_{1}$ are the ratios of the vapour molecule diameter $\left(d_{\mathrm{v}}\right)$ to the initial and final particle diameter, respectively. The mass $\left(m_{\mathrm{v}}\right)$ and density $\left(\rho_{\mathrm{v}}\right)$ of $\mathrm{H}_{2} \mathrm{SO}_{4}$ applied in this study are $135 \mathrm{amu}$ and $1650 \mathrm{~kg} \mathrm{~m}^{-3}$, respectively, corresponding to hydrated $\mathrm{H}_{2} \mathrm{SO}_{4}$ molecules (Kurtén et al., 2007). It should note that Eq. (8) was developed specially for particle with diameter of 3-7 nm. For larger particles $(>10 \mathrm{~nm}$, the case in this study), this method gives similar results to that calculated using the Fuchs-Sutugin approach (Nieminen et al., 2010). The calculated $C_{\mathrm{GR}=1 \mathrm{nmh}^{-1} \mathrm{H}_{2} \mathrm{SO}_{4}}$ may be an underestimate because it is assumed that every $\mathrm{H}_{2} \mathrm{SO}_{4}$ molecule colliding with the particle is attached to it which is not necessarily the case.

Then the growth rate contributed by $\mathrm{H}_{2} \mathrm{SO}_{4}$ condensation during the time period used for the determination of GR is calculated directly as

$$
\mathrm{GR}_{\mathrm{H}_{2} \mathrm{SO}_{4}}=\left[\mathrm{H}_{2} \mathrm{SO}_{4}\right]_{\text {det }} / C_{\mathrm{GR}=1 \mathrm{nmh}^{-1}, \mathrm{H}_{2} \mathrm{SO}_{4}} \text {, }
$$

where $\left[\mathrm{H}_{2} \mathrm{SO}_{4}\right]_{\text {det }}$ is the median value from the measured $\mathrm{H}_{2} \mathrm{SO}_{4}$ concentration during the timeframe for the determination of GR. Here, the $\mathrm{GR}_{\mathrm{H}_{2} \mathrm{SO}_{4}}$ calculated from Eq. (9) is

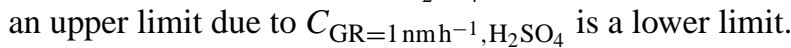

For a spherical particle, its volume change $(\Delta v)$ due to condensational growth within the time interval of $\Delta t$ can be simply calculated:

$$
\begin{gathered}
\Delta v=\frac{\pi}{6} \cdot\left(D_{\mathrm{p}_{\mathrm{t}}}^{3}-D_{\mathrm{p}_{0}}^{3}\right)=\frac{\pi}{6} \cdot\left(D_{\mathrm{p}_{\mathrm{t}}}-D_{\mathrm{p}_{0}}\right) \\
\cdot\left(D_{\mathrm{p}_{\mathrm{t}}}^{2}+D_{\mathrm{p}_{\mathrm{t}}} D_{\mathrm{p}_{0}}+D_{\mathrm{p}_{0}}^{2}\right) .
\end{gathered}
$$

Here

$D_{\mathrm{p}_{\mathrm{t}}}-D_{\mathrm{p}_{0}}=\mathrm{GR}_{\mathrm{obs}} \cdot \Delta t$,

where $D_{\mathrm{p}_{\mathrm{t}}}$ and $D_{\mathrm{p}_{0}}$ are the GMDs at time $t=0$ and $t=\Delta t$, respectively.

The observed growth rate can be presented as the sum of the growth rates due to $\mathrm{H}_{2} \mathrm{SO}_{4}\left(\mathrm{GR}_{\mathrm{H}_{2} \mathrm{SO}_{4}}\right)$ and organic vapors $\left(\mathrm{GR}_{\mathrm{org}}\right)$ condensation (Paasonen et al., 2010):

$\mathrm{GR}_{\mathrm{obs}}=\mathrm{GR}_{\mathrm{H}_{2} \mathrm{SO}_{4}}+\mathrm{GR}_{\mathrm{Org}}$.

By combing Eqs. (10-12), the overall change of particle volume concentration can be separated into two fractions, contributing by $\mathrm{H}_{2} \mathrm{SO}_{4}$ and organic vapors condensation. The fraction contributed by $\mathrm{H}_{2} \mathrm{SO}_{4}$ can be presented as

$\Delta v_{\mathrm{H}_{2} \mathrm{SO}_{4}}=\frac{\pi}{6} \cdot\left(D_{\mathrm{p}_{\mathrm{t}}}^{2}+D_{\mathrm{p}_{\mathrm{t}}} D_{\mathrm{p}_{0}}+D_{\mathrm{p}_{0}}^{2}\right) \cdot \mathrm{GR}_{\mathrm{H}_{2} \mathrm{SO}_{4}} \cdot \Delta t$.

We assumed that the original particle only consists of ammonium sulfate. Then, the volume fraction of $\left(\mathrm{NH}_{4}\right)_{2} \mathrm{SO}_{4}$ in total particle volume $\left(V_{\mathrm{t}}\right), \varepsilon_{\left(\mathrm{NH}_{4}\right) 2 \mathrm{SO}_{4}}$, can be estimated as

$\varepsilon_{\left(\mathrm{NH}_{4}\right) 2 \mathrm{SO}_{4}}=\frac{v_{0}+\Delta v_{\mathrm{H}_{2} \mathrm{SO}_{4}}}{\pi \cdot D_{\mathrm{p}_{\mathrm{t}}}^{3} / 6}$,

where $v_{0}$ is the original particle volume at time 0 . Here, assuming original particle as ammonium sulfate may not cause larger error due to the tiny mass compared to the particles after growing.

As mentioned above, the $\mathrm{GR}_{\mathrm{H}_{2} \mathrm{SO}_{4}}$ is an upper limit, hence $\Delta_{\mathrm{vH}_{2} \mathrm{SO}_{4}}$ in Eq. (13) is an upper limit. Thus, the volume fraction of $\left(\mathrm{NH}_{4}\right)_{2} \mathrm{SO}_{4}$ calculated from Eq. (14) is upper estimation. One should also keep in mind that the neutralization of $\mathrm{H}_{2} \mathrm{SO}_{4}$ by $\mathrm{NH}_{3}$ could also lead to the increase in particle volume, which was not considered in Eq. (13).

\section{Results}

\subsection{The observations of NPF events}

Two NPF events were observed on October $12(\mathrm{DOY}=284)$ and $14(\mathrm{DOY}=286)$. The temporal evolution of the particle number size distribution at Goldlauter and Schmücke research stations and the wind direction and speed at Schmücke site are displayed in Fig. 1. On 12 October, the event started at noon, i.e., at a time when temperature was rapidly increasing, and RH decreasing. During this event, northeast 


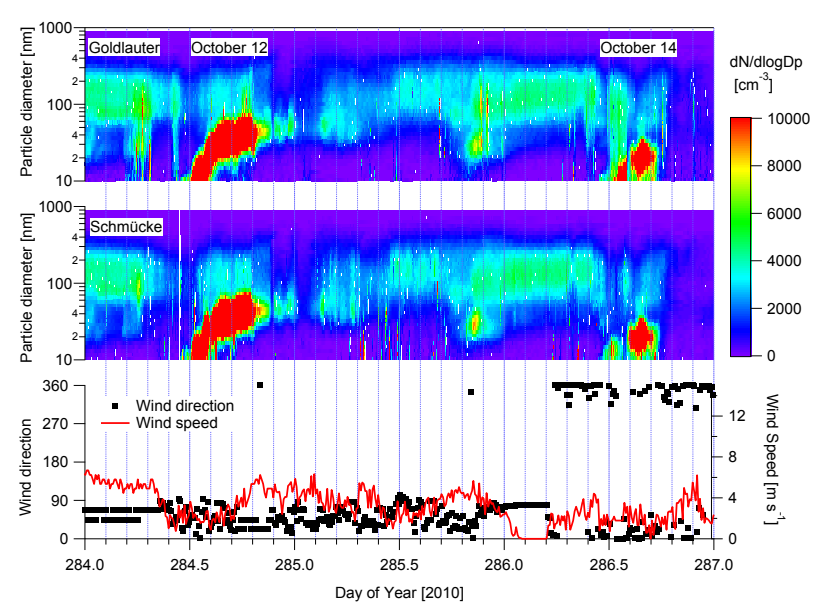

Fig. 1. The evolution of particle number size distribution and weather conditions on 12 and 14 October 2010.

winds prevailed at wind speeds around $2 \mathrm{~m} \mathrm{~s}^{-1}$. As shown in Fig. 2a, no changes in the pathway of air mass arriving at the sampling site were observed during the course of NPF event on 12 October. This event lasted several hours and showed a classical clear growth process.

The second event occurred on 14 October, starting at 11:00, and is also associated with a decreasing RH and an increasing temperature. At 14:00, the event was interrupted when the wind direction switched from south to north. Afterwards, a burst in nucleation mode with relatively larger particles was observed. They showed no significant growth until the event ended at around 18:00. On 14 October, the backward trajectories showed that the air mass significantly changed at noon, as shown in Fig. 2b. After 14:00, the air parcels spent less time over continental areas in contrast to those before 14:00. This may bring clean air, which contains less condensable vapors.

As shown in Fig. 3 the burst in $10-25 \mathrm{~nm}$ particle number concentration was not accompanied by a $\mathrm{SO}_{2}$ spike, thus confirming that the newly formed particles were not produced inside a plume of any nearby source. Both NPF events occurred when the $\mathrm{H}_{2} \mathrm{SO}_{4}$ concentration was relatively high. This is consistent with the previous studies showing that $\mathrm{H}_{2} \mathrm{SO}_{4}$ plays an important role in atmospheric nucleation and early growth (e.g., Birmili et al., 2003; Kulmala et al., 2004). During the NPF event on October 12 , mean $\mathrm{NH}_{3}$ and $\mathrm{O}_{3}$ concentrations are $0.7 \mu \mathrm{g} \mathrm{m}^{-3}$ and $16.5 \mathrm{ppb}$, respectively. In contrast, on October 14 a much lower $\mathrm{NH}_{3}$ concentration $\left(0.09 \mu \mathrm{g} \mathrm{m}^{-3}\right)$ and higher $\mathrm{O}_{3}$ concentration $(28.0 \mathrm{ppbv})$ were observed, as shown in Fig. 3.

\subsection{Particle hygroscopicity during NPF events}

As shown in Fig. 4, the GMDs of newly formed particles increased from $10 \mathrm{~nm}$ to $45 \mathrm{~nm}$ between 13:00 and 20:00 on 12 October. During this event, the HGFs of $30,35,40$,
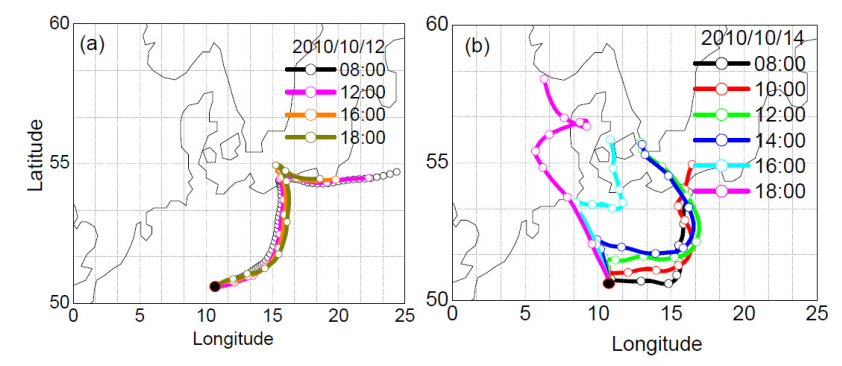

Fig. 2. $72 \mathrm{~h}$ backward trajectory of the air mass $(800 \mathrm{~m}$ above ground level) arriving at the sampling site during NPF events. The black dots in the plot indicate the measurement site.

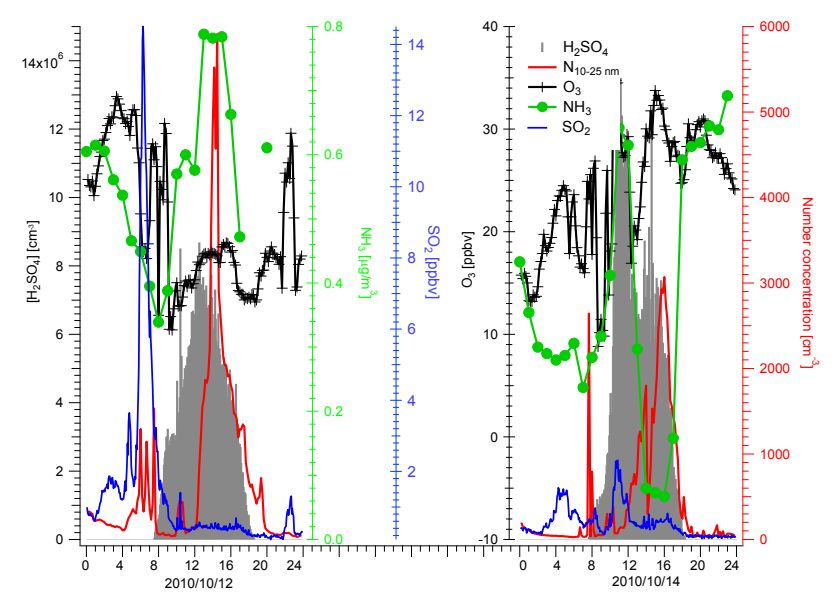

Fig. 3. Time series of trace gases concentration and particle number concentration of nuclei mode on NPF days.

and $45 \mathrm{~nm}$ particles ranged from 1.4 to 1.55 , which is much higher than that (HGFs of 30 and $50 \mathrm{~nm}$ particles are around 1.3) observed by Ehn et al. (2007). On 14 October, the significant change in GMDs was not observed during the event because the event was prematurely cut off due to an air mass change (see Fig. 2b). The HGFs of 25 and $30 \mathrm{~nm}$ particles were between 1.2 and 1.35. The HGFs showed a decreasing trend during the course of the event. This phenomenon was independent of particle size for both events.

As shown in Fig. 4a2, the soluble equivalent volume fraction of nucleation mode particles was between 0.6 and 0.7 on 12 October. During the subsequent particle growth, the soluble fraction decreased. Such a decrease in particle hygroscopicity along with modal diameter growth was also observed in previous experiments in Finland (e.g., Ehn et al., 2007; Kulmala et al., 2001). The significant decline took place between 18:00 and 20:00. This is because the $\mathrm{H}_{2} \mathrm{SO}_{4}$ concentration decreased significantly, thereby the $\mathrm{H}_{2} \mathrm{SO}_{4}$ condensation played a minor role in particle growth during this timeframe. Simultaneously, ambient temperature decreased from 9 to $4{ }^{\circ} \mathrm{C}$. Lower temperature facilitates the 

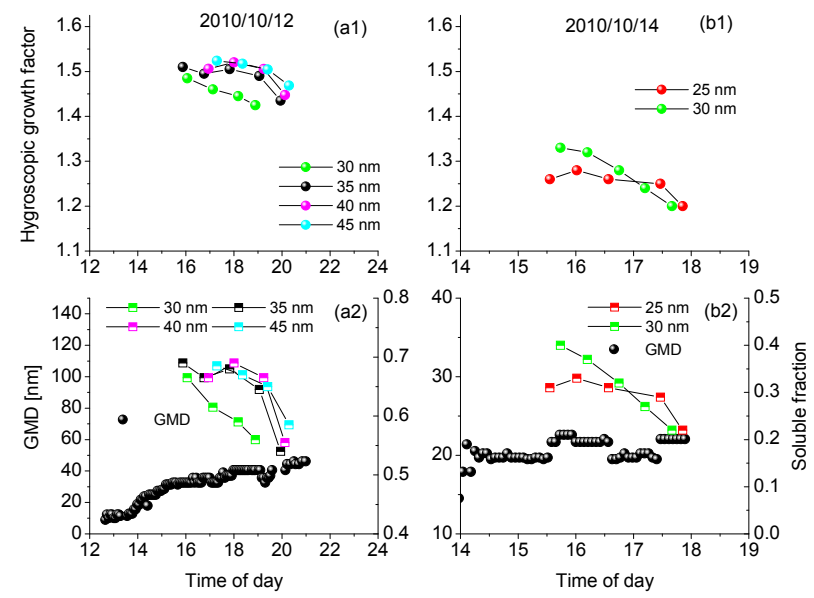

Fig. 4. The temporal evolution of GMD, HGF, and the soluble equivalent fraction $\left(\varepsilon_{\mathrm{H}_{2}} \mathrm{SO}_{4}\right.$-equivalent $)$ during the two NPF events. Time is indicated in local time.

condensation of semi-volatile organic vapors onto the newly formed particles.

On 14 October, the soluble fraction accounts for $30 \%$ of $25 \mathrm{~nm}$ particles at 15:30. In comparison with 12 October, this can be interpreted that organic condensable vapors contributed more to the particle growth at smaller nucleation mode particle sizes. On 14 October, no obvious particle growth could be observed as a result of the air mass change, whereas the soluble fraction of $30 \mathrm{~nm}$ particle decreased to $20 \%$ at the end of event. One possible reason is chemical reactions occurred in the particle phase and produced less hydrophilic compounds. Recently, laboratory experiments gave evidences that organic vapors (2,4-hexadienal, glyoxal and trimethylamine) enhance the growth of $\mathrm{H}_{2} \mathrm{SO}_{4}$ nanoparticles by producing oligomers, polymers and alkylammonium sulfates in the particle phase (Wang et al., 2010). In comparison with ammonium sulfate and sulfuric acid, these compounds have lower hygroscopicity. Another possible reason is more hydrophobic compounds condensed on particles and make particle grow, whereas, the transport and dilution of spatially inhomogeneous aerosols may cause no obvious growth in nucleation mode.

\subsection{Discussion of the chemical species contributing to particle growth}

Table 2 gives a summary of the calculated parameters during the course of the NPF events. The $\left[\mathrm{H}_{2} \mathrm{SO}_{4}\right]$ in the table means the median sulfuric acid concentration during the time period listed in the first column of Table 1. By considering the uncertainty of $40 \%$ in $\left[\mathrm{H}_{2} \mathrm{SO}_{4}\right]$ estimation, the GR contributed by $\mathrm{H}_{2} \mathrm{SO}_{4}$ condensation $\left(\mathrm{GR}_{\mathrm{H}_{2} \mathrm{SO}_{4}}\right)$ ranged from 0.16 to $0.39 \mathrm{~nm} \mathrm{~h}^{-1}$ on 12 October. On average, the $\mathrm{GR}_{\mathrm{H}_{2} \mathrm{SO}_{4}}$ only accounts for around $6.5 \%$ of the observed growth rate $\left(\mathrm{GR}_{\mathrm{obs}}=4.2 \mathrm{~nm} \mathrm{~h}^{-1}\right)$. Several previous studies also reported that the participation of $\mathrm{H}_{2} \mathrm{SO}_{4}$ to the nucleation mode particle growth rates is below $10 \%$ in Hyytiälä, Melpitz, Heidelberg, and Hohenpeissenberg (Boy et al., 2005; Paasonen et al., 2010; Fiedler et al., 2005). After ruling out $\mathrm{H}_{2} \mathrm{SO}_{4}$ condensation as sources of particle growth, low volatile organics may be potential contributors to the remaining growth rate.

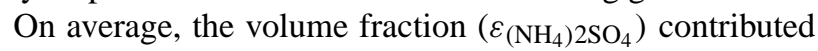
by $\mathrm{H}_{2} \mathrm{SO}_{4}$ condensation is between $4.9-10.1 \%$ during the NPF event on 12 October. By comparing the soluble fraction $\left(\varepsilon_{\mathrm{H}_{2} \mathrm{SO}_{4} \text {-equivalent }}=58.5 \pm 2.9 \%\right)$ derived HTDMA, one can find that only a minor soluble fraction can be explained by $\mathrm{H}_{2} \mathrm{SO}_{4}$ condensation. This may indicate that some other soluble chemical compounds contributing to the particle growth. Recently, amines in forming organic salts were proposed to be a pathway for contributing to atmospheric nanoparticle growth (Smith et al., 2010; Barsanti et al., 2009). Amines are stronger bases than ammonium and have been shown to displace ammonium from ammonium sulfate (Bzdek et al., 2010; Qiu et al., 2011). Smith and coworkers (2010) have shown that alkylammonium carboxylate salts account for $20-50 \%$ of the mass of freshly nucleated particles in locations that include Atlanta, Mexico City, Boulder, and Hyytiälä, while sulfates account for only about $10 \%$. A field measurement performed at a fairly remote mid-level mountain site (The Sierra Nevada Mountain in California), which is similar to our study showed a lack of a correlation between particles with sulfate and ammonium during the NPF events (Creamean et al., 2011). Creamean et al. (2011) found that amines and sulfate present within the same newly formed individual particle, implying amines could be responsible for particle growth. Moreover, laboratory measurements of alkyl-ammonium-carboxylate salt nanoparticles showed only slightly lower hygroscopicity than ammonium sulfate nanoparticles (Smith et al., 2010). Therefore, amines may partly explain the missing source of soluble fraction.

During the event on 14 October, the median $\mathrm{H}_{2} \mathrm{SO}_{4}$ concentration is $4.1 \times 10^{6}$ molecule $\mathrm{cm}^{-3}$. Correspondingly, the estimated growth rate is $0.14-0.32 \mathrm{~nm} \mathrm{~h}^{-1}$. This may cause an increase in particle hygroscopicity. However, the HTDMA measurements show an inverse pattern with decreasing soluble fraction. This observation reinforced that the condensation of organic vapor or chemical reactions in the particulate phase may play a key role in the evolvement of newly formed particles during this event.

\subsection{Comparison between $\mathbf{G R}_{\mathrm{obs}}$ and $\mathbf{G R}_{\mathrm{Lag}}$}

The particle growth rate $\mathrm{GR}_{\mathrm{Lag}}$ is now calculated using Lagrangian consideration. The calculation is based on the picture that particles are formed in the upwind region of the HCCT area, and subsequently transported across the measurement sites. For the methodological comparison of growth rates, the NPF event on 12 October 2010 is analyzed. Due 
Table 2. The observed and calculated growth rate.

\begin{tabular}{lllllll}
\hline Time period & $\mathrm{GMD}^{\mathrm{a}}$ & {$\left[\mathrm{H}_{2} \mathrm{SO}_{4}\right] \# \mathrm{~cm}^{-3}$} & $\mathrm{GR}_{\mathrm{obs}} \mathrm{nm} \mathrm{h}^{-1}$ & $\mathrm{GR}_{\mathrm{H}_{2} \mathrm{SO}_{4} \mathrm{~nm} \mathrm{~h}^{-1}}$ & $\varepsilon_{\mathrm{H}_{2} \mathrm{SO}_{4}}$ & $\varepsilon_{\mathrm{H}_{2} \mathrm{SO}_{4}-\mathrm{equivalent}^{\mathrm{b}}}$ \\
\hline 13:00-20:00, 12 Oct & 45 & $5.1 \times 10^{6}$ & 4.2 & $0.16-0.39$ & $4.9-10.1 \%$ & $58.5 \pm 2.9 \%$ \\
15:30-18:00, 14 Oct & 25 & $4.1 \times 10^{6}$ & 0 & $0.14-0.32$ & $8.6-11.4 \%$ & $22.0 \pm 1.1 \%$ \\
\hline
\end{tabular}

${ }^{a}$ The particle diameter reached after the growth of newly formed particle at the end of time period given in the first column. ${ }^{b}$ The water-soluble fraction of the particles with the same size of GMDs was calculated from Eq. (3).

to it is foggy at Gehlberg station, here Schmücke and Goldlauter stations are considered only (see Supplement).

Calculating $\mathrm{GR}_{\mathrm{Lag}}$ requires an analysis of the atmospheric flow across the sites Schmücke (upwind) and Goldlauter (downwind). Besides pure meteorological considerations involving temperature, wind speed and wind direction, we chose the number concentration of $102 \mathrm{~nm}$ particles $\left(N_{102}\right)$ as a preferential tracer for air flow connectivity. One particular reason is that an examination of particle size distributions during HCCT suggested that this particle size range was the least influenced by any particle formation, deposition, or cloud activation processes during transport. (Details of this topic are not shown here; they will be part of a forthcoming paper in this special issue.)

Figure 1 shows that the wind direction at Schmücke straddled around $45^{\circ}$ (northeast) on 12 October. The average wind speed was $2.3 \mathrm{~m} \mathrm{~s}^{-1}$ during the NPF event. Figure 5a shows similar levels of $N_{102}$ at Schmücke and Goldlauter between 12:00 and 18:00 LT. These arguments indicate a direct flow connection between Schmücke and Goldlauter. At this wind speed, the travel time of the air parcel was estimated to be $25 \mathrm{~min}$. This travel time agrees with the time delay in the number of concentrations of $19 \mathrm{~nm}$ particles at Schmücke and $22 \mathrm{~nm}$ particles at Goldlauter (shown in Fig. 5b), i.e., the observations are consistent with the picture of particle formation upwind the HCCT sites and subsequent transport of that air parcel across the study area. Here, the number concentration of $22 \mathrm{~nm}$ particles at Goldlauter is taken considering that $19 \mathrm{~nm}$ particles will grow to a larger size when they traveled from Schmücke to Goldlauter. For the evaluation of Eq. (7) we assume this observed time difference $\Delta T$ of $25 \mathrm{~min}$.

We subsequently evaluated differences in the nucleation mode particle size between Schmücke and Goldlauter stations by comparing the log-normal modal diameters obtained from a least-squares fitting routine. The size difference $\mathrm{GR}_{\mathrm{Lag}}$ could be calculated at the time resolution of the SMPS measurements, i.e., every $5 \mathrm{~min}$. Averaging over the time period 13:00-18:00 LT yields a mean particle growth rate $3.8( \pm 2.6) \mathrm{nm} \mathrm{h}^{-1}$ obtained from this inter-site data comparison. During this period, $\mathrm{GR}_{\mathrm{obs}}$ calculated from Eq. (6) is $5.0 \mathrm{~nm} \mathrm{~h}^{-1}$, i.e., $24 \%$ higher than $\mathrm{GR}_{\mathrm{Lag}}$. In view of the considerable uncertainties involved in both methods (we estimate the uncertainty of $\mathrm{GR}_{\mathrm{obs}}$ to amount to roughly a factor of two), we consider both values consistent.

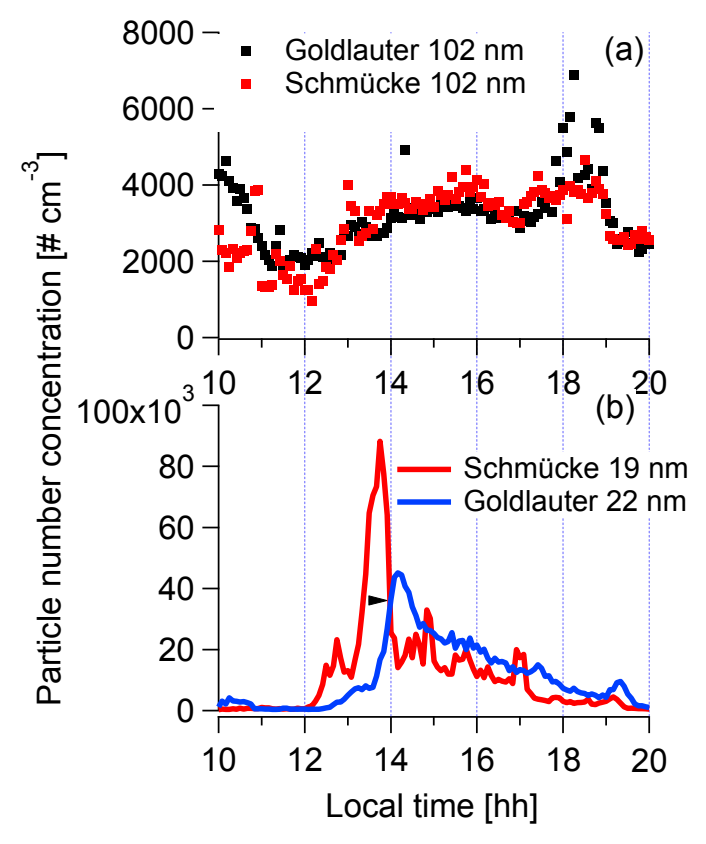

Fig. 5. The time series of particle number concentration during the NPF event on 12 October.

\section{Conclusions}

The particle hygroscopicity of the newly formed particles was investigated to analyze the chemical species contributing to particle growth during the NPF events at a mid-level mountain range, Thüringer Wald, in central Germany. Two cases with and without clear growth process are analyzed in this study. A significant difference in particle hygroscopicity was observed between the two NPF events, indicating that the chemical species driving particle growing were not exactly the same. During both events, the hygroscopic growth of newly formed particles decreased with particle growing. Apparently, the chemical nature of the condensing vapors changed during the particle growth process from more to less hygroscopic species.

During the NPF event with clear growth, the hygroscopic growth factor of newly formed particles ranged from 1.4 to 1.55. On average, the particle growth rate contributing by $\mathrm{H}_{2} \mathrm{SO}_{4}$ condensation only accounts for around $6.5 \%$ of the observed growth rate. Estimations showed that sulfuric acid 
condensation explained, however, only around $10 \%$ of that soluble particle fraction; therefore, the formation of additional water-soluble matter appears imperative to explain the missing soluble fraction. Recent-identified amines in newly formed particles may partly explain the missing source of soluble fraction. The particle growth rate was respectively determined using log-normal distribution function method $\left(\mathrm{GR}_{\mathrm{obs}}\right)$ and Langragian consideration $\left(\mathrm{GR}_{\mathrm{Lag}}\right) . \mathrm{GR}_{\mathrm{Lag}}$ and $\mathrm{GR}_{\text {obs }}$ are respectively $3.8( \pm 2.6) \mathrm{nm} \mathrm{h}^{-1}$ and $5 \mathrm{~nm} \mathrm{~h}^{-1}$. In view of the considerable uncertainties involved in both methods, we consider the growth rates derived from both methods consistent.

Edited by: G. McFiggans

\section{Supplementary material related to this article is available online at: http://www.atmos-chem-phys.net/13/ 6637/2013/acp-13-6637-2013-supplement.pdf.}

\section{References}

Asmi, E., Frey, A., Virkkula, A., Ehn, M., Manninen, H. E., Timonen, H., Tolonen-Kivimäki, O., Aurela, M., Hillamo, R., and Kulmala, M.: Hygroscopicity and chemical composition of Antarctic sub-micrometre aerosol particles and observations of new particle formation, Atmos. Chem. Phys., 10, 4253-4271, doi:10.5194/acp-10-4253-2010, 2010.

Barsanti, K. C., McMurry, P. H., and Smith, J. N.: The potential contribution of organic salts to new particle growth, Atmos. Chem. Phys., 9, 2949-2957, doi:10.5194/acp-9-2949-2009, 2009.

Birmili, W., Berresheim, H., Plass-Dülmer, C., Elste, T., Gilge, S., Wiedensohler, A., and Uhrner, U.: The Hohenpeissenberg aerosol formation experiment (HAFEX): a long-term study including size-resolved aerosol, $\mathrm{H}_{2} \mathrm{SO}_{4}, \mathrm{OH}$, and monoterpenes measurements, Atmos. Chem. Phys., 3, 361-376, doi:10.5194/acp-3-361-2003, 2003.

Boy, M., Kulmala, M., Ruuskanen, T. M., Pihlatie, M., Reissell, A., Aalto, P. P., Keronen, P., Dal Maso, M., Hellen, H., Hakola, H., Jansson, R., Hanke, M., and Arnold, F.: Sulphuric acid closure and contribution to nucleation mode particle growth, Atmos. Chem. Phys., 5, 863-878, doi:10.5194/acp-5-863-2005, 2005.

Brus, D., Neitola, K., Hyvärinen, A.-P., Petäjä, T., Vanhanen, J., Sipilä, M., Paasonen, P., Kulmala, M., and Lihavainen, H.: Homogenous nucleation of sulfuric acid and water at close to atmospherically relevant conditions, Atmos. Chem. Phys., 11, 52775287, doi:10.5194/acp-11-5277-2011, 2011.

Bzdek, B. R., Ridge, D. P., and Johnston, M. V.: Amine exchange into ammonium bisulfate and ammonium nitrate nuclei, Atmos. Chem. Phys., 10, 3495-3503, doi:10.5194/acp-10-3495-2010, 2010.

Creamean, J. M., Ault, A. P., Ten Hoeve, J. E., Jacobson, M. Z., Roberts, G. C., and Prather, K. A.: Measurements of aerosol chemistry during new particle formation events at a remote rural mountain site, Environ. Sci. Technol., 45, 8208-8216, doi:10.1021/es103692f, 2011.

Dal Maso, M., Kulmala, M., Riipinen, I., Wagner, R., Hussein, T., Aalto, P. P., and Lehtinen, A. K. E. J.: Formation and growth of fresh atmospheric aerosols: Eight years of aerosol size distribution data from smear ii, hyytiälä, finland, Boreal Environ. Res., 10, 323-336, 2005.

DeCarlo, P. F., Kimmel, J. R., Trimborn, A., Northway, M. J., Jayne, J. T., Aiken, A. C., Gonin, M., Fuhrer, K., Horvath, T., Docherty, K. S., Worsnop, D. R., and Jimenez, J. L.: Field-deployable, high-resolution, time-of-flight aerosol mass spectrometer, Anal. Chem., 78, 8281-8289, doi:10.1021/ac061249n, 2006.

Draxler, R. R. and Hess, G. D.: An overview of the hysplit_4 modelling system for trajectories, dispersion and deposition, Aust. Meteorol. Mag., 47, 295-308, 1998.

Ehn, M., Petäjä, T., Aufmhoff, H., Aalto, P., Hämeri, K., Arnold, F., Laaksonen, A., and Kulmala, M.: Hygroscopic properties of ultrafine aerosol particles in the boreal forest: diurnal variation, solubility and the influence of sulfuric acid, Atmos. Chem. Phys., 7, 211-222, doi:10.5194/acp-7-211-2007, 2007.

Fiedler, V., Dal Maso, M., Boy, M., Aufmhoff, H., Hoffmann, J., Schuck, T., Birmili, W., Hanke, M., Uecker, J., Arnold, F., and Kulmala, M.: The contribution of sulphuric acid to atmospheric particle formation and growth: a comparison between boundary layers in Northern and Central Europe, Atmos. Chem. Phys., 5, 1773-1785, doi:10.5194/acp-5-1773-2005, 2005.

Gysel, M., McFiggans, G. B., and Coe, H.: Inversion of tandem differential mobility analyser (tdma) measurements, J. Aerosol Sci., 40, 134-151, doi:10.1016/j.jaerosci.2008.07.013, 2009.

Hämeri, K., Väkevä, M., Aalto, P. P., Kulmala, M., Swietlicki, E., Zhou, J., Seidl, W., Becker, E., and O'Dowd, C. D.: Hygroscopic and ccn properties of aerosol particles in boreal forests, Tellus B, 53, 359-379, doi:10.1034/j.1600-0889.2001.530404.x, 2001.

Herrmann, H., Wolke, R., Müller, K., Brüggemann, E., Gnauk, T., Barzaghi, P., Mertes, S., Lehmann, K., Massling, A., Birmili, W., Wiedensohler, A., Wieprecht, W., Acker, K., Jaeschke, W., Kramberger, H., Svrcina, B., Bächmann, K., Collett Jr, J. L., Galgon, D., Schwirn, K., Nowak, A., van Pinxteren, D., Plewka, A., Chemnitzer, R., Rüd, C., Hofmann, D., Tilgner, A., Diehl, K., Heinold, B., Hinneburg, D., Knoth, O., Sehili, A. M., Simmel, M., Wurzler, S., Majdik, Z., Mauersberger, G., and Müller, F.: Febuko and modmep: Field measurements and modelling of aerosol and cloud multiphase processes, Atmos. Environ., 39, 4169-4183, doi:10.1016/j.atmosenv.2005.02.004, 2005.

IPCC: Intergovernmental Panel on Climate Change. Report., Cambridge Univ Press, Cambridge, UK, available: http://www.ipcc. ch/ipccreports/ar4-wg1.htm, 2007.

Kiendler-Scharr, A., Wildt, J., Maso, M. D., Hohaus, T., Kleist, E., Mentel, T. F., Tillmann, R., Uerlings, R., Schurr, U., and Wahner, A.: New particle formation in forests inhibited by isoprene emissions, Nature, 461, 381-384, 2009.

Kulmala, M., Maso, M. D., MÄKel̈̈, J. M., Pirjola, L., VÄKevÄ, M., Aalto, P., Miikkulainen, P., HÄMeri, K., and O'Dowd, C. D.: On the formation, growth and composition of nucleation mode particles, Tellus B, 53, 479-490, doi:10.1034/j.16000889.2001.530411.x, 2001.

Kulmala, M., Vehkamäki, H., Petäjä, T., Dal Maso, M., Lauri, A., Kerminen, V. M., Birmili, W., and McMurry, P. H.: Formation and growth rates of ultrafine atmospheric particles: A review of observations, J. Aerosol Sci., 35, 143-176, doi:10.1016/j.jaerosci.2003.10.003, 2004.

Kulmala, M., Petäjä, T., Mönkkönen, P., Koponen, I. K., Dal Maso, M., Aalto, P. P., Lehtinen, K. E. J., and Kerminen, V.-M.: On the 
growth of nucleation mode particles: source rates of condensable vapor in polluted and clean environments, Atmos. Chem. Phys., 5, 409-416, doi:10.5194/acp-5-409-2005, 2005.

Kulmala, M., Lehtinen, K. E. J., and Laaksonen, A.: Cluster activation theory as an explanation of the linear dependence between formation rate of $3 \mathrm{~nm}$ particles and sulphuric acid concentration, Atmos. Chem. Phys., 6, 787-793, doi:10.5194/acp-6-787-2006, 2006.

Kulmala, M., Arola, A., Nieminen, T., Riuttanen, L., Sogacheva, L., de Leeuw, G., Kerminen, V.-M., and Lehtinen, K. E. J.: The first estimates of global nucleation mode aerosol concentrations based on satellite measurements, Atmos. Chem. Phys., 11, 10791-10801, doi:10.5194/acp-11-10791-2011, 2011.

Kurtén, T., Torpo, L., Ding, C.-G., Vehkamäki, H., Sundberg, M. R., Laasonen, K., and Kulmala, M.: A density functional study on water-sulfuric acid-ammonia clusters and implications for atmospheric cluster formation, J. Geophys. Res.-Atmos., 112, D04210, doi:10.1029/2006jd007391, 2007.

Laaksonen, A., Hamed, A., Joutsensaari, J., Hiltunen, L., Cavalli, F., Junkermann, W., Asmi, A., Fuzzi, S., and Facchini, M. C.: Cloud condensation nucleus production from nucleation events at a highly polluted region, Geophys. Res. Lett., 32, L06812, doi:10.1029/2004g1022092, 2005.

Lee, K. W., Chen, J., and Gieseke, J. A.: Log-normally preserving size distribution for brownian coagulation in the free-molecule regime, Aerosol Sci. Technol., 3, 53-62, doi:10.1080/02786828408958993, 1984.

Lee, K. W., Curtis, L. A., and Chen, H.: An analytic solution to free molecule aerosol coagulation, Aerosol Sci. Technol., 12, 457462, doi:10.1080/02786829008959360, 1990.

Malm, W. C. and Kreidenweis, S. M.: The effects of models of aerosol hygroscopicity on the apportionment of extinction, Atmos. Environ., 31, 1965-1976, doi:10.1016/s13522310(96)00355-x, 1997.

Maßling, A., Wiedensohler, A., Busch, B., Neusüß, C., Quinn, P., Bates, T., and Covert, D.: Hygroscopic properties of different aerosol types over the Atlantic and Indian Oceans, Atmos. Chem. Phys., 3, 1377-1397, doi:10.5194/acp-3-1377-2003, 2003.

Massling, A., Niedermeier, N., Hennig, T., Fors, E. O., Swietlicki, E., Ehn, M., Hämeri, K., Villani, P., Laj, P., Good, N., McFiggans, G., and Wiedensohler, A.: Results and recommendations from an intercomparison of six Hygroscopicity-TDMA systems, Atmos. Meas. Tech., 4, 485-497, doi:10.5194/amt-4-485-2011, 2011.

Mikkonen, S., Romakkaniemi, S., Smith, J. N., Korhonen, H., Petäjä, T., Plass-Duelmer, C., Boy, M., McMurry, P. H., Lehtinen, K. E. J., Joutsensaari, J., Hamed, A., Mauldin III, R. L., Birmili, W., Spindler, G., Arnold, F., Kulmala, M., and Laaksonen, A.: A statistical proxy for sulphuric acid concentration, Atmos. Chem. Phys., 11, 11319-11334, doi:10.5194/acp-11-11319-2011, 2011.

Modini, R. L., Ristovski, Z. D., Johnson, G. R., He, C., Surawski, N., Morawska, L., Suni, T., and Kulmala, M.: New particle formation and growth at a remote, sub-tropical coastal location, Atmos. Chem. Phys., 9, 7607-7621, doi:10.5194/acp-9-7607-2009, 2009.

Nieminen, T., Lehtinen, K. E. J., and Kulmala, M.: Sub-10 nm particle growth by vapor condensation - effects of vapor molecule size and particle thermal speed, Atmos. Chem. Phys., 10, 97739779, doi:10.5194/acp-10-9773-2010, 2010.
Paasonen, P., Nieminen, T., Asmi, E., Manninen, H. E., Petäjä, T., Plass-Dülmer, C., Flentje, H., Birmili, W., Wiedensohler, A., Hõrrak, U., Metzger, A., Hamed, A., Laaksonen, A., Facchini, M. C., Kerminen, V.-M., and Kulmala, M.: On the roles of sulphuric acid and low-volatility organic vapours in the initial steps of atmospheric new particle formation, Atmos. Chem. Phys., 10, 11223-11242, doi:10.5194/acp-10-11223-2010, 2010.

Petäjä, T., Kerminen, V.-M., Dal Maso, M., Junninen, H., Koponen, I. K., Hussein, T., Aalto, P. P., Andronopoulos, S., Robin, D., Hämeri, K., Bartzis, J. G., and Kulmala, M.: Submicron atmospheric aerosols in the surroundings of Marseille and Athens: physical characterization and new particle formation, Atmos. Chem. Phys., 7, 2705-2720, doi:10.5194/acp-72705-2007, 2007.

Pierce, J. R., Riipinen, I., Kulmala, M., Ehn, M., Petäjä, T., Junninen, H., Worsnop, D. R., and Donahue, N. M.: Quantification of the volatility of secondary organic compounds in ultrafine particles during nucleation events, Atmos. Chem. Phys., 11, 90199036, doi:10.5194/acp-11-9019-2011, 2011.

Potukuchi, S. and Wexler, A. S.: Identifying solid-aqueous phase transitions in atmospheric aerosols - i. Neutral-acidity solutions, Atmos. Environ., 29, 1663-1676, doi:10.1016/13522310(95)00074-9, 1995.

Qiu, C., Wang, L., Lal, V., Khalizov, A. F., and Zhang, R.: Heterogeneous reactions of alkylamines with ammonium sulfate and ammonium bisulfate, Environ. Sci. Technol., 45, 4748-4755, doi:10.1021/es1043112, 2011.

Ristovski, Z. D., Suni, T., Kulmala, M., Boy, M., Meyer, N. K., Duplissy, J., Turnipseed, A., Morawska, L., and Baltensperger, U.: The role of sulphates and organic vapours in growth of newly formed particles in a eucalypt forest, Atmos. Chem. Phys., 10, 2919-2926, doi:10.5194/acp-10-2919-2010, 2010.

Sakurai, H., Fink, M. A., McMurry, P. H., Mauldin, L., Moore, K. F., Smith, J. N., and Eisele, F. L.: Hygroscopicity and volatility of 4-10 nm particles during summertime atmospheric nucleation events in urban atlanta, J. Geophys. Res., 110, D22S04, doi:10.1029/2005jd005918, 2005.

Sipilä, M., Berndt, T., Petäjä, T., Brus, D., Vanhanen, J., Stratmann, F., Patokoski, J., Mauldin, R. L., Hyvärinen, A.-P., Lihavainen, H., and Kulmala, M.: The role of sulfuric acid in atmospheric nucleation, Science, 327, 1243-1246, 2010.

Smith, J. N., Moore, K. F., McMurry, P. H., and Eisele, F. L.: Atmospheric measurements of sub-20 nm diameter particle chemical composition by thermal desorption chemical ionization mass spectrometry, Aerosol Sci. Technol., 38, 100-110, doi:10.1080/02786820490249036, 2004.

Smith, J. N., Moore, K. F., Eisele, F. L., Voisin, D., Ghimire, A. K., Sakurai, H., and McMurry, P. H.: Chemical composition of atmospheric nanoparticles during nucleation events in atlanta, J. Geophys. Res., 110, D22S03, doi:10.1029/2005jd005912, 2005.

Smith, J. N., Barsanti, K. C., Friedli, H. R., Ehn, M., Kulmala, M., Collins, D. R., Scheckman, J. H., Williams, B. J., and and McMurry, P. H.: Observations of aminium salts in atmospheric nanoparticles and possible climatic implications, P. Natl. Acad. Sci. USA, 107, 6634-6639, 2010.

Spracklen, D. V., Carslaw, K. S., Kulmala, M., Kerminen, V.-M., Sihto, S.-L., Riipinen, I., Merikanto, J., Mann, G. W., Chipperfield, M. P., Wiedensohler, A., Birmili, W., and Lihavainen, H.: Contribution of particle formation to global cloud conden- 
sation nuclei concentrations, Geophys. Res. Lett., 35, L06808, doi:10.1029/2007g1033038, 2008.

Stokes, R. H. and Robinson, R. A.: Interactions in aqueous nonelectrolyte solutions. I. Solute-solvent equilibria, J. Phys. Chem., 70, 2126-2130, 1966.

Stolzenburg, M. R., McMurry, P. H., Sakurai, H., Smith, J. N., Mauldin, R. L., III, Eisele, F. L., and Clement, C. F.: Growth rates of freshly nucleated atmospheric particles in atlanta, J. Geophys. Res., 110, D22S05, doi:10.1029/2005jd005935, 2005.

Swietlicki, E., Zhou, J., Berg, O. H., Martinsson, B. G., Frank, G., Cederfelt, S.-I., Dusek, U., Berner, A., Birmili, W., Wiedensohler, A., Yuskiewicz, B., and Bower, K. N.: A closure study of sub-micrometer aerosol particle hygroscopic behaviour, Atmos. Res., 50, 205-240, doi:10.1016/s0169-8095(98)00105-7, 1999.

Tang, I. N. and Munkelwitz, H. R.: Water activities, densities, and refractive indices of aqueous sulfates and sodium nitrate droplets of atmospheric importance, J. Geophys. Res., 99, 18801-18808, doi:10.1029/94jd01345, 1994.

ten Brink, H., Otjes, R., Jongejan, P., and Slanina, S.: An instrument for semi-continuous monitoring of the size-distribution of nitrate, ammonium, sulphate and chloride in aerosol, Atmos. Environ., 41, 2768-2779, doi:10.1016/j.atmosenv.2006.11.041, 2007.

Tuch, T. M., Haudek, A., Müller, T., Nowak, A., Wex, H., and Wiedensohler, A.: Design and performance of an automatic regenerating adsorption aerosol dryer for continuous operation at monitoring sites, Atmos. Meas. Tech., 2, 417-422, doi:10.5194/amt-2-417-2009, 2009.

Väkevä, M., Kulmala, M., Stratmann, F., and Hämeri, K.: Field measurements of hygroscopic properties and state of mixing of nucleation mode particles, Atmos. Chem. Phys., 2, 55-66, doi:10.5194/acp-2-55-2002, 2002.

Varutbangkul, V., Brechtel, F. J., Bahreini, R., Ng, N. L., Keywood, M. D., Kroll, J. H., Flagan, R. C., Seinfeld, J. H., Lee, A., and Goldstein, A. H.: Hygroscopicity of secondary organic aerosols formed by oxidation of cycloalkenes, monoterpenes, sesquiterpenes, and related compounds, Atmos. Chem. Phys., 6, 23672388, doi:10.5194/acp-6-2367-2006, 2006.

Virkkula, A., Van Dingenen, R., Raes, F., and Hjorth, J.: Hygroscopic properties of aerosol formed by oxidation of limonene, $\alpha$-pinene, and $\beta$-pinene, J. Geophys. Res., 104, 3569-3579, doi:10.1029/1998jd100017, 1999.

Wang, L., Khalizov, A. F., Zheng, J., Xu, W., Ma, Y., Lal, V., and Zhang, R.: Atmospheric nanoparticles formed from heterogeneous reactions of organics, Nature Geosci., 3, 238-242, 2010.

Wang, M. and Penner, J. E.: Aerosol indirect forcing in a global model with particle nucleation, Atmos. Chem. Phys., 9, 239-260, doi:10.5194/acp-9-239-2009, 2009.

Wehner, B., Petäjä, T., Boy, M., Engler, C., Birmili, W., Tuch, T., Wiedensohler, A., and Kulmala, M.: The contribution of sulfuric acid and non-volatile compounds on the growth of freshly formed atmospheric aerosols, Geophys. Res. Lett., 32, L17810, doi:10.1029/2005g1023827, 2005.
Wiedensohler, A., Cheng, Y. F., Nowak, A., Wehner, B., Achtert, P., Berghof, M., Birmili, W., Wu, Z. J., Hu, M., Zhu, T., Takegawa, N., Kita, K., Kondo, Y., Lou, S. R., Hofzumahaus, A., Holland, F., Wahner, A., Gunthe, S. S., Rose, D., Su, H., and Pöschl, U.: Rapid aerosol particle growth and increase of cloud condensation nucleus activity by secondary aerosol formation and condensation: A case study for regional air pollution in northeastern china, J. Geophys. Res., 114, D00G08, doi:10.1029/2008jd010884, 2009.

Wiedensohler, A., Birmili, W., Nowak, A., Sonntag, A., Weinhold, K., Merkel, M., Wehner, B., Tuch, T., Pfeifer, S., Fiebig, M., Fjäraa, A. M., Asmi, E., Sellegri, K., Depuy, R., Venzac, H., Villani, P., Laj, P., Aalto, P., Ogren, J. A., Swietlicki, E., Williams, P., Roldin, P., Quincey, P., Hüglin, C., Fierz-Schmidhauser, R., Gysel, M., Weingartner, E., Riccobono, F., Santos, S., Grüning, C., Faloon, K., Beddows, D., Harrison, R., Monahan, C., Jennings, S. G., O’Dowd, C. D., Marinoni, A., Horn, H.-G., Keck, L., Jiang, J., Scheckman, J., McMurry, P. H., Deng, Z., Zhao, C. S., Moerman, M., Henzing, B., de Leeuw, G., Löschau, G., and Bastian, S.: Mobility particle size spectrometers: harmonization of technical standards and data structure to facilitate high quality long-term observations of atmospheric particle number size distributions, Atmos. Meas. Tech., 5, 657-685, doi:10.5194/amt5-657-2012, 2012.

Wu, Z. J., Nowak, A., Poulain, L., Herrmann, H., and Wiedensohler, A.: Hygroscopic behavior of atmospherically relevant water-soluble carboxylic salts and their influence on the water uptake of ammonium sulfate, Atmos. Chem. Phys., 11, 1261712626, doi:10.5194/acp-11-12617-2011, 2011.

Yue, D. L., Hu, M., Zhang, R. Y., Wang, Z. B., Zheng, J., Wu, Z. J., Wiedensohler, A., He, L. Y., Huang, X. F., and Zhu, T.: The roles of sulfuric acid in new particle formation and growth in the mega-city of Beijing, Atmos. Chem. Phys., 10, 4953-4960, doi:10.5194/acp-10-4953-2010, 2010.

Yue, D. L., Hu, M., Zhang, R. Y., Wu, Z. J., Su, H., Wang, Z. B., Peng, J. F., He, L. Y., Huang, X. F., Gong, Y. G., and Wiedensohler, A.: Potential contribution of new particle formation to cloud condensation nuclei in beijing, Atmos. Environ., 45, 60706077, doi:10.1016/j.atmosenv.2011.07.037, 2011.

Zdanovskii, B.: Novyi metod rascheta rastvorimostei elektrolitov v mnogokomponentnykh sistema, Zh. Fiz. Khim+, 22, 14781485, 1486-1495, 1948.

Zhang, R., Suh, I., Zhao, J., Zhang, D., Fortner, E. C., Tie, X., Molina, L. T., and Molina, M. J.: Atmospheric new particle formation enhanced by organic acids, Science, 304, 1487-1490, doi:10.1126/science.1095139, 2004.

Zordan, C. A., Wang, S., and Johnston, M. V.: Time-resolved chemical composition of individual nanoparticles in urban air, Environ. Sci. Technol., 42, 6631-6636, doi:10.1021/es800880z, 2008. 